Turkish Journal of Geriatrics

DOI: 10.31086/tigeri.2018238910

2018:21 (2):109-114

- Feriha TEMIZEL ${ }^{1}$

- Serkan UÇKUN'

- Tamer KUZUCUOĞLU1

- Gülten ARSLAN ${ }^{1}$

- Banu ÇEVIK ${ }^{1}$

\section{THE EFFECTS OF COMORBIDITIES ON INTENSIVE CARE ADMISSION IN ELDERLY PATIENTS UNDERGOING HIP SURGERIOUS}

\section{A Bstract}

Introduction: We aimed to compare patients aged $\geq 75$ in the intensive care unit with those in orthopedics clinic following hip replacement with respect to age, preoperative comorbidity, anesthesia types, length of hospital stay, and mortality.

Materials and Methods: Patients aged $\geq 75$ who underwent hip replacement at our hospital due to intertrochanteric femoral fracture in 2011-2016 were evaluated. Patients aged $<75$ with severe organ failure and hemorrhagic diathesis were excluded. Age, sex, comorbidity, anesthesia types, length of stay in the hospital before surgery and in the intensive care unit, and mortalities were evaluated in 130 patients. Patients were divided into two groups: patients in postoperative intensive care unit and those in postoperative orthopedic clinic. A p-value of $<0.05$ was considered statistically significant.

Results: Mean age and the prevalence of hypertension, diabetes mellitus, congestive heart failure, and chronic obstructive pulmonary disease were significantly higher in patients in the intensive care unit than in those in postoperative orthopedic clinic. No difference was observed between the groups in anesthesia types. Length of hospital stay was significantly longer in patients in the intensive care unit. In logistic regression analysis, older age and presence of chronic obstructive pulmonary disease had significant effect on admission to the intensive care unit.

Discussion: We believe that detailed preoperative evaluation, optimization of patient condition using current treatments when necessary, and postoperative intensive care unit monitoring are beneficial for patients with hip fracture aged $\geq 84$ with comorbidities, such as hypertension, diabetes mellitus, congestive heart failure, and chronic obstructive pulmonary disease.

Keywords: orthopedics, hip fractures, critical care, comorbidity

ARAŞTIRMA

Feriha TEMiZEL

Health Science University, Kartal Dr. Lütfi Kırdar

Training and Research Hospital, Department of

Anesthesiology and Reanimation

İstanbul, Türkiye

Phone: 02164583000

e-mail: ferihatemizel@gmail.com

Received: $04 / 01 / 2018$

Accepted: 09/04/2018

Health Science University, Kartal Dr. Lütfi Kırdar Training and Research Hospital, Department of Anesthesiology and Reanimation istanbul, Türkiye

\section{KALÇA CERRAHISI GEÇiREN ILERI YAŞ HASTALARDA KOMORBID HASTALIKLARIN YOĞUN BAKIM YATIŞI ÜZERINE ETKISI}

Öz

Giriş: Çalışmamızda kalça cerrahisi sonrası yoğun bakımda ve ortopedi kliniği'nde takip edilen 75 yaş ve üzeri hastaların; yaş, preoperatif komorbidite, anestezi yöntemleri, hastanede yatış süreleri ve mortalite açııından karşılaştırııması amaçlanmıştır.

Gereç ve Yöntem: Hastanemizde 2011-2016 tarihleri arasında 75 yaşüzeri, intertrokanterik femur fraktürü nedeniyle parsiyel kalça protezi uygulanan hastaların kayıtları incelendi. Yetmiş beş yaş altı, ileri derecede organ yetmezliği ve kanama diyatezi olan hastalar çalışma dışı bırakıldı. Toplam 130 hastanın yaş, cinsiyet, komorbidite varlığı, anestezi yöntemi, ameliyat öncesi yatış, yoğun bakımda ve hastanede yatış süreleri ve mortaliteleri istatistiksel açıdan değerlendirildi. $p<0.05$ anlamlı kabul edildi.

Bulgular: Postoperatif yoğun bakım ünitesinde takip edilen hastaların, yaş ortalaması, hipertansiyon, diyabetes mellitus, konjestif kalp yetmezliği, kronik obstrüktif akciğer hastalığı varlığı postoperatif ortopedi kliniğinde takip edilenlerden istatistiksel olarak anlamlı derecede yüksek bulundu. Anestezi yöntemi açısından iki grup arasında fark gözlenmedi. Yoğun bakım ünitesinde yatan hastaların hastanede yatış süreleri diğer gruba göre anlamlı olarak uzun idi. Logistik regresyon analizinde; Illeri yaş, kronik obstrüktif akciğer hastalığı varlığı, yoğun bakım ünitesinde yatışı etkileyen faktörler olarak anlamlı kabul edildi.

Sonuç: Sonuç olarak 84 yaş üstünde, komorbidite olarak diyabetes mellitus, hipertansiyon, konjestif kalp yetmezliği, kronik obstrüktif akciğer hastalığı, bulunan geriatrik kalça kırığı hastalarının postoperatif yoğun bakım ünitesinde takibi gerektiğini düşünmekteyiz.

Anahtar sözcükler: ortopedi, kalça kırıkları, yoğun bakım, komorbidite 


\section{INTRODUCTION}

Hip fractures are one of the most hazardous types of fractures in terms of prognosis, as they may result in chronic pain, poor quality of life, and immobility, especially in the elderly population. Recently, as life expectancy has increased, the geriatric population is also rapi dly increasing. According to data from the Turkish Statistical Institute, while the ratio of elderly population in 2012 was $7.5 \%$, it is expected to increase up to $10.2 \%$ by 2023 . With the population increase, the incidence of hip fracture is expected to increase in our country. Age is a distinctive risk factor in terms of complications and mortality (1, 2). However, it is possible to operate on patients suffering from hip fractures regardless of age (3, 4). As the large part of these patients are ASA III group patients experiencing comorbidities, hip replacement surgeries may result in high mortality rates due to the characteristics of patients and surgery. To reduce mortality rates, it is advised that preoperative evaluations of patients should be carefully conducted, provisions should be made for the safety of the operation by applying current multidisciplinary treatments when necessary, and patients should be closely monitored by admitting them to postoperative intensive care units when necessary. The present study aimed to compare patients in postoperative intensive care units with those in orthopedic clinics with respect to age, preoperative comorbidity, anesthesia types, length of hospital stay, and mortality following surgery for intertrochanteric femoral fracture.

\section{MATERIALS AND METHODS}

We obtained ethics approval from the hospital Ethics Committee, following which our study was conducted on 130 patients aged $\geq 75$ who were followed up in the Orthopedics and Traumatology Clinic and intensive care units at the University of Health Sciences, Kartal Training and Research Hospital, due to intertrochanteric femoral fracture. Patients were divided into two groups: those who were in postoperative intensive care unit (ICU) [the
ICU (+) group] ( $n=70)$ and those who were followed up in orthopedics clinic [the ICU $(-)$ group] $(n=60)$. Patient data from their admission files and electronic records were retrospectively evaluated. They were evaluated with respect to age; sex; presence of comorbidities; such as chronic obstructive pulmonary disease (COPD), congestive heart failure (CHF), hypertension (HT), diabetes mellitus (DM), chronic kidney failure (CKF), and dementia; operation site; anesthesia types (general/spinal); preoperative-postoperative service; postoperative intensive care; and total length of hospital stay along with mortality rates.

In our study, Number Cruncher Statistical System 2007 Statistical Software (Utah, USA) package program was used for statistical analyses. In addition to the complementary statistical methods (mean, standard deviation), independent t-test was used in the comparison of the two groups, and chi-square test was used in the comparison of quantitative data. Factors affecting admission to ICU were determined via logistic regression (LGR) analysis. To determine point estimation of factors affecting ICU admission, sensitivity, specificity, positive predictive value, negative predictive value, which includes the area under the receiver operating characteristic curve were calculated. Results were evaluated according to a p-value of $<0.05$ and confidence interval of $95 \%$.

\section{RESULTS}

The mean age of the ICU (+) group significantly higher than that of the ICU $(-)$ group ( $p=0.006$ ). No statistically significant difference was observed between the distribution of sex and region of operation in both groups (table 1).

The prevalence of comorbidities such as HT ( $p$ $=0.007), \mathrm{DM}(\mathrm{p}=0.007), \mathrm{CHF}(\mathrm{p}=0.002), \mathrm{COPD}$ $(p=0.01)$ in the ICU (+) group was significantly higher than that in the ICU (-) group. There was no statistically significant difference between the distribution of CKF ( $p=0.526)$ and dementia $(p=0.909)$ in ICU (-) and ICU (+) groups (table 2). 
There was no statistically significant difference between the total length of hospital stay in the ICU $(-)$ and ICU $(+)$ groups $(p=0.001)$ (table 3 ).

The mortality rate of the ICU (+) group was significantly higher than that of the ICU (-) group $(p=0.017)$. No statistically significant difference was observed between the distribution of anesthesia types administered in the ICU (+) and ICU (-) groups $(p=0.115)($ table 4$)$

In the univariate analysis, older age [odds ratio (OR) 1.09 (1.0-1.17)], prevalence of HT [OR 0.38
(0.19-0.78)], DM [OR 3.18 (1.34-7.45)], CHF [OR 13.45 (1.7-16.24)], and COPD [OR $0.10(0.01-0.93)]$ were determined as factors affecting ICU admission. (OR value should be clarified in detail.)

In the LGR analysis by which we evaluated age, $H T, D M, C H F$, and COPD, the prevalence of HT ( $p$ $=0.235), \mathrm{DM}(p=0.540)$, and CHF ( $p=0.203)$ were found to be statistically significant $(p>0.05)$. Older age $(p=0.027)$ and the prevalence of COPD $(p=$ $0.043)$ were found to be statistically significant $(p<$ 0.05) (table 5).

Table 1. Demographic comparison of patients

\begin{tabular}{|c|c|c|c|c|c|c|c|}
\hline \multirow[b]{2}{*}{ Age } & & & \multicolumn{2}{|l|}{$\operatorname{ICU}(-) n=60$} & \multicolumn{2}{|l|}{$\operatorname{ICU}(+) n=70$} & \multirow{2}{*}{$\begin{array}{c}P \\
0.006\end{array}$} \\
\hline & & & $81.33 \pm 5.16$ & & $84.26 \pm 6.46$ & & \\
\hline \multirow{2}{*}{ Sex } & & Male & 22 & $36.67 \%$ & 19 & $27.14 \%$ & \multirow{2}{*}{0.244} \\
\hline & & Female & 38 & $63.33 \%$ & 51 & $72.86 \%$ & \\
\hline \multirow{2}{*}{$\begin{array}{l}\text { Region } \\
\text { operation }\end{array}$} & \multirow[t]{2}{*}{ of } & Right & 30 & $50.00 \%$ & 30 & $42.86 \%$ & \multirow{2}{*}{0.415} \\
\hline & & Left & 30 & $50.00 \%$ & 40 & $42.86 \%$ & \\
\hline
\end{tabular}

$p<0.05$ : significant

Table 2. Comparison of comorbid diseases

\begin{tabular}{|c|c|c|c|c|c|c|}
\hline \multirow{3}{*}{$\begin{array}{l}\text { Disease } \\
\text { Hypertension }\end{array}$} & \multirow{3}{*}{$\begin{array}{l}\text { No } \\
\text { Yes }\end{array}$} & \multicolumn{2}{|c|}{$\operatorname{ICU}(-) n=60$} & \multicolumn{2}{|c|}{$\operatorname{ICU}(+) n=70$} & \multirow{3}{*}{$\begin{array}{c}P \\
0.007\end{array}$} \\
\hline & & 39 & $65.00 \%$ & 29 & $41.43 \%$ & \\
\hline & & 21 & $35.00 \%$ & 41 & $58.57 \%$ & \\
\hline \multirow{2}{*}{ DM } & No & 51 & $85.00 \%$ & 45 & $64.29 \%$ & \multirow{2}{*}{0.007} \\
\hline & Yes & 9 & $15.00 \%$ & 25 & $35.71 \%$ & \\
\hline \multirow{2}{*}{$\mathrm{CHF}$} & No & 59 & $98.33 \%$ & 57 & $81.43 \%$ & \multirow{2}{*}{0.002} \\
\hline & Yes & 1 & $1.67 \%$ & 13 & $18.57 \%$ & \\
\hline \multirow{2}{*}{ COPD } & No & 59 & $98.33 \%$ & 60 & $85.71 \%$ & \multirow{2}{*}{0.01} \\
\hline & Yes & 1 & $1.67 \%$ & 10 & $14.29 \%$ & \\
\hline \multirow{2}{*}{ CKF } & No & 57 & $95.00 \%$ & 68 & $97.14 \%$ & \multirow{2}{*}{0.526} \\
\hline & Yes & 3 & $5.00 \%$ & 2 & $2.86 \%$ & \\
\hline \multirow{2}{*}{ Dementia } & No & 51 & $85.00 \%$ & 60 & $85.71 \%$ & \multirow{2}{*}{0.909} \\
\hline & Yes & 9 & $15.00 \%$ & 10 & $14.29 \%$ & \\
\hline
\end{tabular}

DM, diabetes mellitus; $C H F$, congestive heart failure; COPD, chronic obstructive pulmonary disease; CKF, chronic kidney failure $p<0.05$ : significant 
Table 3. Length of hospital stay (days)

\begin{tabular}{llll}
\hline & ICU $(-) \mathbf{n}=60$ & ICU $(+) \mathbf{n}=70$ & $\mathbf{p}$ \\
\hline $\begin{array}{l}\text { Length of service } \\
\text { hospitalization }\end{array}$ & $4.56 \pm 1.91$ & $4.62 \pm 3.03$ & 0.902 \\
Total length of hospital stay & $9.83 \pm 3.24$ & $14.04 \pm 9.01$ & 0.001 \\
\hline
\end{tabular}

$p<0.05$ : significant

Table 4. Comparison of mortality rates and anesthesia types

\begin{tabular}{|c|c|c|c|c|c|c|}
\hline \multirow{3}{*}{ Prognosis } & \multirow{3}{*}{$\begin{array}{l}\text { Alive } \\
\text { Ex }\end{array}$} & \multicolumn{2}{|c|}{$\operatorname{ICU}(-) n=60$} & \multicolumn{2}{|c|}{$\operatorname{ICU}(+) n=70$} & \multirow{3}{*}{$\begin{array}{c}\mathbf{p} \\
0.017\end{array}$} \\
\hline & & 59 & $98.33 \%$ & 61 & $87.14 \%$ & \\
\hline & & 1 & $1.67 \%$ & 9 & $12.86 \%$ & \\
\hline \multirow{2}{*}{$\begin{array}{l}\text { Anesthesia } \\
\text { type }\end{array}$} & Spinal & 54 & $90.00 \%$ & 56 & $80.00 \%$ & \multirow{2}{*}{0.115} \\
\hline & General & 6 & $10.00 \%$ & 14 & $20.00 \%$ & \\
\hline
\end{tabular}

$p<0.05$ : significant

Table 5. Evaluation of comorbid diseases with respect to logistic regression

\begin{tabular}{lccrr}
\hline & \multicolumn{2}{c}{ Univariate OR } & \multicolumn{2}{c}{ Multivariate OR } \\
\cline { 2 - 5 } & $\mathbf{p}$ & OR \%95 GA & \multicolumn{1}{c}{ P } & OR \%95 GA \\
\hline Age & 0.022 & $1.09(1.02-1.16)$ & 0.027 & $1.09(1.00-1.17)$ \\
HT & 0.007 & $0.38(0.19-0.78)$ & 0.235 & $0.58(0.23-1.40)$ \\
DM & 0.007 & $3.18(1.34-7.45)$ & 0.540 & $0.67(0.19-2.41)$ \\
CHF & 0.002 & $13.45(1.7-16.24)$ & 0.203 & $0.24(0.03-2.14)$ \\
COPD & 0.01 & $0.10(0.01-0.82)$ & 0.043 & $0.10(0.01-0.93)$ \\
\hline
\end{tabular}

\section{DISCUSSION}

Hip fracture is one of the most frequent traumatic diseases with serious mortality and morbidity rates that result in hospitalization in elderly patients (5). Elderly patients with hip fractures are very sensitive to cardiac and respiratory problems, which may develop as a result of fractures as well as surgical stress. It is reported that the 1-year mortality in patients with hip fractures is $24 \%-29 \%$ (6). High mortality rate is related to the general status of the patients before surgery rather than the surgical intervention itself (7). In a study by de Luice et al. in Denmark, it was demonstrated that hip fractures resulted in an increase in mortality rates in their own right (8).

In elderly patients, it is mandatory to plan a multidisciplinary preoperative evaluation and treatment in surgical decision-making to minimize preoperative and postoperative risks. It is important 
that the surgical decision is made as soon as possible. Moran et al. reported that mortality is higher in patients who waited to undergo surgery for $\geq 5$ days ((9). In the present study, the waiting period before surgery was $<5$ days; it was observed that this period did not have any effect on the decision of admission to ICU.

Some studies have shown that due to their age, presence of comorbidities, and increase in the number of comorbidities in geriatric patients with hip fractures result in an increase in the requirement of intensive care and the incidence of mortality (10, 11). In our study, all patients were examined with respect to $\mathrm{DM}, \mathrm{HT}, \mathrm{CHF}, \mathrm{COPD}, \mathrm{CKF}$, and dementia. As a result of these examinations, we detected that $\mathrm{DM}, \mathrm{HT}, \mathrm{CHF}$, and COPD were significantly factors that contributed to admission of patients to ICU ( $p$ $<0.05)$

In a study conducted on 554,733 cases that were operated due to femoral fracture, Smith et al. specified abnormal ECG, cognitive disorder, old age $>85$, limited pre-fracture mobility, male sex, appropriate geriatric care units, high ASA, and high Charlson comorbidity scores as parameters for evaluating mortality (12). In a study that included 751,232 patients with hip fractures, Erickson et al. reported that the probability of postoperative mortality of patients aged $>84$ was higher (13). The fact that these studies included patients aged $\geq 85$ was compatible with our study.

Hu et al. examined 12 parameters for 1 year in 75 patients who underwent hip replacement. Old age, high ASA, diabetes and cardiac disease parameters were found to be preoperative mortality indicators (14); these are consistent with the present study. However, in the present study, we found that dementia, which they found to be a preoperative mortality indicator, was not a statistically significant parameter for admission to ICU.

Cree et al. also stated that dementia increased mortality rates following hip fractures (2). However, in our study, we observed that dementia and CKF factors were responsible for admission of patients to ICUs. This difference may be due to the fact that the present study only evaluated factors affecting the admission to ICU rather than factors affecting mortality.

We found that the anesthesia type (general/ spinal) did not have a significant effect on the hemodynamic and cardiovascular parameters of preoperative and postoperative patients and was not significant in patients' transfer to ICUs.

Peled et al. stated that regional anesthesia had positive effects on 109 elderly patients with COPD (11). They reported that 10 of these patients died and that the probability of complications increased in those who underwent general anesthesia.

Memtsoudis et al. observed that there were fewer complications in hip and femur operations that are performed via neuraxial blockade than with general anesthesia (15).

In another study, anesthesia type did not increase the incidence of complications in hip fractures (16). We also detected that anesthesia type did not increase the incidence of complications in our patients.

It is necessary to specify elderly patients as a separate group with specific medical and surgical characteristics with respect to healing and future care (11). Although orthogeriatric units have initiated improvements with respect to care of geriatric patients who are admitted to hospitals due to hip fractures since the 1950s, hip fractures are still a serious socio-economic problem in western countries (17).

Some authors have reported that multidisciplinary geriatric care reduces hospital mortality and complications $(17,18,19)$. We also believe that ICU monitoring of complicated cases reduces mortality.

In conclusion, we believe that detailed preoperative evaluation is crucial in improving 
postoperative prognosis in geriatric patients aged $\geq 84$ with hip fractures and comorbidities, such as DM, HT, CHF, and COPD. Optimization of patient condition via utilization of current treatments and postoperative ICU monitoring are required as well as more frequent vital signs monitoring for a rapid intervention.

\section{REFERENCES}

1. Bhandari $M, K o o H$, Saunders $L$ et al. Predictors of InHospital Mortality Following Operative Management of Hip Fractures. International Journal of Surgical Investigation 1999; 1(4):319-26. (PMID:12774456).

2. Cree M, Soskolne CL, Belseck E, et al. Mortality and Institutionalization Following Hip Fracture. Journal of the American Geriatrics Society 2000;48(3):283-8. (PMID:10733054).

3. Bergeron E, Moore L, Fournier K, et al. Patients with isolated hip fracture must be considered for surgery irrespectively of their age, comorbidity status and provenance: a statement applicable even to nonagerians. Arch Orthop Trauma Surg. 2009;129(11):1549-55. (PMID:19440727).

4. Pelavski A.D, Colomina M.J, De Miguel M, et al. Demographics of Nonagenarians and Centenarians with a Hip Fracture. Anesth Analg. 2006;103(6):15979. (PMID:17122263).

5. de Leur K, Vroemen JP, Vos DI, et al. Outcome after osteosynthesis of hip fractures in nonagenarians. Clin Interv Aging 2014;9:41-9. (PMID:24379658).

6. Petersen MB, Jorgensen HL, Hansen K, et al . Factors affecting postoperative mortality of patients with displaced femoral neck fracture. Injury 2006;37: 705711.(PMID: 16765352).

7. Roche JJ, Wenn RT, Sahota O, et al. Effect of comorbidities and postoperative complications on mortality after hip fracture in elderly people: prospective observational cohort study. BMJ 2005;331:1374. (PMID:16299013).

8. de Luise C, Brimacombe M, Pedersen L, et al. Chronic Obstructive Pulmonary Disease and Mortality Following Hip Fracture; A Population-Based Cohort Study. European Journal of Epidemiology 2008;23(2):115-22. (PMID:18038248).

9. Moran CG, Wenn RT, Sikand M, et al. Early mortality after hip fracture: is delay before surgery important?. J. Bone Joint Surg Am. 2005;87(3):483-489. (PMID:15741611).
The local ethic committee approval was obtained (2017/514/118/3).

The written informed consent forms were taken from the patients.

The authors have no conflict of interest to declare.

10. Haentjens $P$, Autier $P$, Barette $M$, et al. Survival and functional outcome according to hip fracture type: a one-year prospective cohort study in elderly women with an intertrochanteric or femoral neck fracture. Bone 2007;41(6):958-964. (PMID:17913614).

11. Peled E, Barak M, Keren Y, et al. Predictors for Adverse Outcome in Patients Aged 80 Years and Older Undergoing Emergent Hip Surgery;Gerontology 2009;55(5):517-22. (PMID :19684382).

12. Smith T, Pelpola $K$, Ball $M$, et al. Pre-operative indicators for mortality following hip fracture surgery: a systematic review and meta-analysis. Age Ageing 2014;43(4):464-71. (PMID:24895018).

13. Erickson B.J, Nwachukwu B.U, Kiriakopoulos E, et al. In-hospital mortality risk for femoral neck fractures among patients receiving medicare. Orthopedics 2015;(8):593-596. (PMID:26186321).

14. Hu F, Jiang C, Shen J, et al. Preoperative predictors for mortality following hip fracture surgery: a systematic review and meta-analysis. Injury 2012;43(6):676-85. (PMID:21683355).

15. Memtsoudis S.G, Sun X, Chiu YL, et al. Perioperative Comparative Effectiveness of Anesthetic Technique in Orthopedic Patients .Anesthesiology. 2013;118(5):1046-1058. (PMID:23612126).

16. O'Hara DA, Duff A, Berlin JA, et al. The effect of anesthetic technique on postoperative outcomes in hip fracture repair. Anesthesiology 2000;92(4):94757. ( PMID:10754613).

17. Tarazona-Santabalbina FJ, Belenguer-Varea Á, Rovira E, et al. Orthogeriatric care: improving patient outcomes. Clin Interv Aging 2016 ; 11:84356. (PMID:27445466).

18. Vidan M, Serra JA, Moreno C, et al. Efficacy of a comprehensive geriatric intervention in older patients hospitalized for hip fracture:a randomized, controlled trial. Journal of the American Geriatrics Society 2005;53:1476-82. (PMID:16137275).

19. Wang Y, Tang J, Zhou F, et al. Comprehensive geriatric care reduces acute perioperative delirium in elderly patients with hip fractures: A meta-analysis. Medicine 2017; 96(26):e7361. (PMID:28658156). 